\title{
The Effectivity of Search, Solve, Create, and Share (SSCS) Learning Model on Improving the Critical Thinking Skills of Students in SMA 9 Banda Aceh
}

\author{
A R Handayani \\ Department of Science Education \\ Universitas Syiah Kuala \\ Banda Aceh, Indonesia
}

\author{
Muhibbuddin \\ Department of Biology Education \\ Universitas Syiah Kuala \\ Banda Aceh, Indonesia
}

\author{
Muhammad Syukri*, Elisa \\ Department of Physics Education \\ Universitas Syiah Kuala \\ Banda Aceh, Indonesia \\ *syukri.physics@unsyiah.ac.id
}

\begin{abstract}
Critical thinking skills are fundamental abilities that every student should have in order to manage their behaviour and academic problems. The aim of this study is to determine the effect of the application of the Search Solve Create Share (SSCS) learning model on students' critical thinking skills. The study used Quantitative Approach with Quasi Experimental Method with Pre-test Post-test Control Group Design. The sampling technique was carried out by Random Purposive Sampling way selecting two classes that had comparable ability (in learning physics subject). These two classes then divided into experimental with 30 students, and control group with the same number of students. In the experimental group, The SSCS model was used to treat them, while in the control group direct instruction was used. The data were analysed by comparing the value of $n$-Gain and then tested using the $T$-Test with Independent Sample. The results showed that the average n-Gain had significant different results. The total answer, $n-G a i n$ value for each critical thinking function shows better results in the experimental group than the control group. In general conclusion, the SSCS model has a serious effect on improving students' critical thinking skills.
\end{abstract}

Keywords—search solve create share, critical thinking skills

\section{INTRODUCTION}

Considering that the teacher is directly involved in learning process since planning tell the implementation, the learning success measures is the succeed of learning activities itself [1]. Students learning outcomes are influenced by internal factor such as reduced learning ability or learning loss and environment factors such as learning media, learning facilities and teacher quality [2]. More, several observations says that the students low learning outcomes in recent years have been influenced by a lot of factors, including the method used does not hit the mark and the lack of students' critical thinking skills [3].

Skills of thinking critically in academic aspect are fundamental in preparing students to be able to make their own right decisions, to become mature in thinking, and had better concept in pursuing their goals. In some ways, critical thinking and divergent thinking are compatible. Divergent thinking is a thought process that generates creative ideas by examining many possible solutions. By contrast, Convergent thinking is a way of thinking that focuses on finding a single wellestablished solution to a problem, that do not require significant critical way [4].

Thinking critically is one of the most crucial cognitive skills can develop [5]. The 2015 Program for International Student Assessment (PISA) survey showed, Indonesia was ranked 69 out of 76 countries in matter of poor learning competence which bring low critical thinking skills to students [6].

One of factors lack Critical Thinking Skills (CTS) are caused by learning process which continues to focus on providing the "correct" answer to standard questions that do not necessitate significant creativity, such as most school tasks and standardized multiple-choice tests for intelligence. Whereas critical skills in solving analytical questions often discarded [7]. Critical thinking is composed of several behaviour tendencies (curiosity and open thinking) and knowledge skills (analysis, inference, and evaluation) [8]. Another problem issues, is due to the lack of high-level thinking skills in producing alternative problem solving, one of which is critical thinking purpose [9]. Research from Maulana et al [10], low critical thinking skills are shown by the learning 
process focused on writing books and memorization so that only emphasizes the student's achievement in credits without understanding the concept.

All factors described above, leads to one notable problem, it is about students are not used in high orders thinking skills. Difficulty in understanding concept and formulas (in physics subject) also impact to students credits on National Exam (UN) Data for 2018 shows that the average national examination (UN) for high school student score in Aceh are the lowest from all over the province, it is 40.45. The average high school student score of the UN for physics subject in Banda Aceh in 2018 was 36.48 , it falls steadily since 2016 to 2018. In 2016 the score was 55.21, in 2017 it decreases dramatically into 38.32 and continued to decline in 2018 into 35.18, the lowest level around Indonesia. Based on the data, it is clearly that critical thinking skills are affect the student learning outcomes.

Based on the early observation in SMA Negeri 9 Banda Aceh, information acquired that: (1) Critical thinking skills are in frequently applied in their learnings process (2) There are only 10 students who successfully passed the temperature and heat material exams (physics subject test) (3) students competence in high order thinking skills is rarely applied, even the school has implemented the 2013 curriculum (which focus on HOTS(High Order Thinking Skills)) (4) Learning activities are still based on teacher-centred that causing students less able develop discussion and critical thinking skills in groups, (5) students only relying on the teacher explanation without direct practice or individual rehearsal.

The teacher has tried to help students in the process of learning but has not been able to detect the difficulties because of students different thinking ability. Several methods can be used to solve critical thinking in learnings problems, one of all is by applying learning model that plays an important role in overcoming problems in learning. One of model for learning that fit to the critical thinking problem is the Search, Solve, Create and Share (SSCS) model learning. The SSCS applied as problem solving approach designed to develop critical thinking skills and increase understanding of scientific concepts [11]. The SSCS learning model is a model that give's students the opportunity to explore their thinking so that they can solve problems systematically and actively discuss when the learning going [12]. Through this article is expected to be an extra empirical occurrence of how the SSCS learning model affects the development of critical thinking in high school students, particularly when learning about temperature and heat in class XI physics subject.

\section{RESEARCH METHODS}

The research held in high school SMAN 9 Banda Aceh using quantitative approach with protest post-test control group design. The population in this research were all of student in second grade high school SMAN 9 Banda Aceh. The sample selected by using Purposive Random Sampling Technique. After selecting two classes that have the similar physic ability characteristics, one class was chosen randomly as the experimental group and the other as the control class with each class consisting of 30 students. The indicators measured in this research were students critical thinking skills in temperature and heat physics subject taught using Search, Solve, Create and Share (SSCS) learning model. The instrument used in this research are the 7 themes essay questions to measure critical thinking skills and the 10 items multiple choice questions to measure the results of thinking in the learning, both instruments have been validated and tested. T Test and percentage formula is used in the data analysis technique. The research procedure was, First, both of class are given pretest questions. Second, carried out learning activities as in learning plan (RPP) by applying the SSCS model to the experimental class with direct instruction model of learning. The last, providing post-test questions to both of class in purpose to determine the students learning capability after being treated in the experimental class. Data analysis techniques to determine Critical thinking skills of students were analysed by normality, homogeneity, and the $t$-test of the $\mathrm{N}$-gain to see the increase student critical thinking skills.

\section{RESULTS AND DISCUSSION}

Data on critical thinking skills in statistical tests that are normally distributed and homogeneous can be determined by performing the normality and homogeneity test as a prerequisite for the hypothesis (T Test). The Ch Square Test is used to derive the normality test. The $\mathrm{T}$ Test is used to ascertain the hypothesis test. The n-Gain value of the experimental class and the control class were used as t-test data, in proposing to watch increase value in both variable. The homogeneity was tested by the F-test. Indicators of critical thinking skills used in this study refer to Enns' indicators of critical thinking skills. Students' critical thinking skills are measured through the questions distributed at the end of experiment time. The effect of SSCS in increasing the CTS, the average difference for $\mathrm{n}$-Gain experiment and $\mathrm{n}$-Gain control are tested. More details can be seen in Table 1

TABLE I. AVERAge VALUE TEST FOR N-GAIN EXPERIMENT AND NGAIN CONTROL

\begin{tabular}{|c|c|c|c|c|}
\hline Group & $\begin{array}{c}\text { Average } \\
\text { scores }\end{array}$ & Normality* & $\underset{* *}{\text { Homogeneity }}$ & $\begin{array}{c}\text { Significancy } \\
* * *\end{array}$ \\
\hline $\begin{array}{l}\text { Experime } \\
\text { nt Group }\end{array}$ & 60,80 & $\begin{array}{l}X_{\text {hit }}^{2}<X_{\text {tab }}^{2} \\
(0,02)<(5,991) \\
\text { (Normality) }\end{array}$ & \multirow{2}{*}{$\begin{array}{l}F_{\text {hit }}<F_{\text {tab }} \\
(0,38)<(1,84) \\
\text { (Homogeneity } \\
\text { ) }\end{array}$} & \multirow{2}{*}{$\begin{array}{l}\mathrm{t}_{\text {hit }}<\mathrm{t}_{\text {tab }} \\
(3,09)< \\
(1,68) \\
\text { (Significa } \\
\text { ncy) }\end{array}$} \\
\hline $\begin{array}{l}\text { Control } \\
\text { Group }\end{array}$ & 52,07 & $\begin{array}{l}X_{\text {hit }}^{2}<X_{\text {tab }}^{2} \\
(4,57)<(5,991) \\
\text { (Normality) }\end{array}$ & & \\
\hline
\end{tabular}

Annotation:

- *) = Chi Square Test $\left(\right.$ Normality, score $\mathrm{x}^{2}{ }_{\text {hit }}<$ $\left.\mathrm{x}_{\text {tab, }}^{2} \alpha=0,05\right)$

- **) $\quad=\mathrm{F}$ test $\left(\right.$ Homogeneity, score $\mathrm{F}_{\text {hit }}<\mathrm{F}_{\mathrm{tab}}$ $\alpha=0,05$ 


$$
\text { - } * * *) \quad=\mathrm{t} \text { test }\left(\text { Significant, } \mathrm{t}_{\mathrm{hit}}<\mathrm{t}_{\mathrm{tab}}, \alpha=0,05\right)
$$

The normality test finding obtained in both the experimental and control groups were generally distributed. The homogeneity test was then performed to see if the data had a homogeneous variance. So that the experimental class and control class data had homogeneous data variance, it could be inferred. The mean test is used to test both normal and homogeneous data, and the results of the analyses show that the average $n$-Gain value of the experimental and control classes is different, after calculating with the t test it is known that $t_{\text {hit }}>t_{\text {tab }}$ or $3,09>1.68$ so that the conclusion of the value of the experimental class and the control class is significantly different. It is clearly that there is a significant better difference to student critical thinking skills in the application of the SSCS learning model. The results of the CTSn-Gain data analysis can be seen in the following table. Based on the table, the average pretest and post-test scores in the experiment and control class varies for each observed indicator. The criteria for each indicator observed in the experimental class were in the good category, while the control class was also in the good category and the ample category. The increase in the average score of the student CTS indicator is given in the CTSndcator recapitulaton by looking for the $n$-Gan value of the pretest post-test experimental class and control class in the pretest post-test experimental class and control class. Table 2 below shows the N-Gain results for the average CTS indicator score.

TABLE II. THE RESULTS OF THE N-GAIN CTS ANALYSIS OF INDICATORS IN THE EXPERIMENT AND CONTROL GROUP

\begin{tabular}{|l|l|l|l|}
\hline \multirow{2}{*}{ No. } & \multicolumn{2}{|c|}{ Indicator } & \multicolumn{2}{c|}{ CTS N-Gain Average } \\
\cline { 3 - 4 } 1 & $\begin{array}{l}\text { Giving simple } \\
\text { explanation }\end{array}$ & 0,49 & 0,47 \\
\hline 2 & Build basic skills & 0,75 & 0,69 \\
\hline 3 & Summarizing & 0,98 & 0,91 \\
\hline 4 & $\begin{array}{l}\text { Provide further } \\
\text { explanation }\end{array}$ & 1,01 & 0,93 \\
\hline 5 & Strategize tactics & 0,79 & 0,67 \\
\hline
\end{tabular}

Table 2 showed the graph of the recapitulation of the nGain results of the average score of the CTS indicator for the experimental and control group from the average score of the pretest and post-test scores on each indicator by looking on the $\mathrm{n}$-Gain value. Based on the table, it can be shown that students in the experimental class control class obtained a variable nGain for each CTSndcator. The category for the experimental class to obtain an n-Gain value denotes that the indicator providing further explanation has the highest value, and it is included in the high category. The lowest $n$-Gain value shown on the indicator provides a simple explanation and is included in the medium category. In the control class there are 3 indicators which are categorized as moderate, it is providing simple explanations, building basic skills and arranging tactical strategies. The highest $\mathrm{n}$-Gain value in the control class is the indicator providing further explanation. Based on the n-Gain graph, it can be concluded that the indicator providing a simple explanation has the lowest $\mathrm{n}$-Gain value compared to other CTS indicators in the experimental and control class.

Based on all indicators, it was discovered that the experimental class pupils' CTS increased more than the control class. The experimental class's average n-Gan value was included in the medium and high categories, while the control class was included in the medium category. The data was in accordance with the findings of the average difference test for the n-Gan data in the table of the n-Gan difference test in general, which proves that there is a significant increase in students' critical thinking for both the experimental and control classes.

The CTS indicator providing further explanation has the highest average $n$-Gain value, means that most students able answering questions that are included in the CTS indicator correctly. In the SSCS learning model there is a solve or problem-solving stage where students doing activities in collecting data, analysing data and make decisions in the group to find solutions (connecting their knowledge with the concepts they are working on). Rakhmi's statement on the solve stage, students had success train their high-order thinking skills when they analyse how to solve problems [13]. The indicator providing a simple explanation that the lowest $n$-Gain average value, this means that only a small percentage of students can properly answer the questions in the CTS indicator.

The factor that affects the improvement of CTS in the experimental class is more significant than the control class is the application of the SSCS learning model. Saregar, et al. revealed that problem solving-based learning are very important to applied because it helps students remember information longer by it is examples, understanding more when given the opportunity to try to solve problems themselves, otherwise they will quickly forget material that is only explained verbally in learning [14].

The increase in critical thinking skills on each indicator with high and significant value is in the experimental class because the usage of the SSCS teaching strategy has invited students to improve thinking skills so that they can comprehend the idea of physics based on a scientific approach to problem solving [15]. Therefore, when faced questions of critical thinking skills, students can answer these questions well. According to Falah's research; Hatari; and Lukitasari; According to Febriyant et al, using the SSCS learning model has a greater impact on improving student CTS than using traditional learning methods [17-19]. The findings of the study show that using the Search, Solve, Create, and Share (SSCS) learning model to improve critical thinking skills has a positive impact (CTS). This is indicated by a significant increase in the CTS test value between before and after the SSCS learning model was applied (pretest and post-test).

\section{CONCLUSION}

Students' critical thinking skills are improved when they use the Search Solve Create and Share learning model. This is proven by the results of the average difference test showing thit 
$<\mathrm{t}_{\text {tab }}$ or 3.09> 1.68. The $\mathrm{n}$-Gain average score for the indicator which has the highest value is the indicator providing further explanation and the lowest $\mathrm{n}$-Gain average score is the indicator providing a simple explanation. It can be concluded that Search, Solve, Create, and Share learning model has a significant impact on students' critical thinking skills.

\section{ACKNOWLEDGMENT}

I would like to thanks to staff of SMA Negeri 9 Banda Aceh for providing a place and time to collecting data research and thanks to the Syiah Kuala University helped make this research done well.

\section{REFERENCES}

[1] R. Zakia, I. Khaldun and R. Safitri, "Pengaruh problem based learning melalui school watching terhadap aktivitas dan hasil belajar siswa pada materi asam basa di SMP," Jurnal Pendidikan Sains Indonesia, vol. 6, no. (1), pp. 46-54, 2018.

[2] N. Sudjana, Dasar-dasar Proses Belajar Mengajar. Bandung: Sinar Baru Algensido Offset, 1989.

[3] I. Israfiddin, A. Gani and S. Saminan, "Penerapan model problem based learninguntuk me ningkatkan sikap ilmiah dan hasil belajar peserta didik pada materi gerak di SMP," Jurnal Pendidikan Sains Indonesia, vol. 4, no. (1), pp. 43-51, 2016

[4] D.K. Filsaisme, Menguak Rahasia Berpikir Kritis Dan Kreatif. Jakarta: Prestasi pustaka, 2008.

[5] K. Kasmadi, A. Gani and Y. Yusrizal, "Model Pembelajaran Learning Cycle 7E Berbantu Ict Untuk Meningkatkan Penguasaan Konsep Dan Ketrampilan Berpikir Kritis Siswa Pada Materi Larutan Penyangga," Jurnal Pendidikan Sains Indonesia (Indonesian Journal of Science Education), vol. 4, no. (2), pp. 106-112, 2016.

[6] B. Milama, E.S. Bahriah and A. Mahmudah, "The effect of Search, Solve, Create, and Share (SSCS) learning model towards student's critical thinking skills," Jurnal Penelitian dan Pembelajaran IPA, vol. 3, no. (2), pp. 112-123, 2017.

[7] Z. Muhammad, "Pengembangan Perangkat Pembelajaran Konsep Proses Fisiologis Tumbuhan Menggunakan Model Inkuiri Terbimbing di SMP," Landasan-Jurnal Ilmiah Kependidikan \& Kemasyarakatan, vol. 9, no. (1), 2014.

[8] I.J. Quitadamo, L.F. Celia, E.J. James and J.K. Marta, "Communitybased Inquiry Improves Critical Thinking in General Education
Biology," CBE-Life Science Education, vol. 7, no. (2), pp. 327-337, 2008

[9] F. Faradhillah and T.F. Sudargo, "Analisis keterampilan berpikir kritis siswaSMP yang diajarkan oleh guru yang sudah dan belum tersertifikasi," Edusains, vol. 8, no. (1), pp. 83-89, 2016.

[10] A. Maulana, K.A. Wancik and S. Sofia, "Penerapan Model Pembelajaran Search Solve Create And Share (Sscs) untuk Meningkatkan Hasil Belajar Siswa di Kelas XI IPA SMA,” Jurnal Penelitian Pendidikan Kimia: Kajian Hasil Penelitian Pendidikan Kimia, vol. 1, no. (1), pp. 9-17, 2014.

[11] A. Saregar, I. Irwandani, A. Abdurrahman, P. Parmin, S. Septiana, R. Diani and R. Sagala, "Temperature and heat learning through SSCS model with scaffolding: Impact on students' critical thinking ability,' Journal for the Education of Gifted Young Scientists, vol. 6, no. (3), pp. 39-54, 2018.

[12] Y. Anwar and Z. Jalil, "Implementasi strategi problem solving dengan menggunakan metode eksperimen untuk meningkatkan minat dan keterampilan berpikir kritis di MAN Gandapuran pada materi gerak harmonic," Jurnal IPA dan Pembelajaran IPA, vol. 1, no. (1), pp. 16-25, 2017.

[13] R.H. Ennis, "Critical Thinking Assessment, "College of Education, vol. 32, no. (3), pp. 179-184, 1993.

[14] D.A. Rakhmi, K. Kartono and M. Zaenuri, "Constructivism mathematics learning with search, solve, create, and share (sscs) model to improve mathematics disposition and student concept understanding of limit function materials of xi natural science class," Unnes Journal of Mathematics Education Research, vol. 7, no. (2), pp. 117-122, 2018.

[15] R. Ramson, Model pembelajaran Search Solve Create and Share untuk meningkatkan pemahaman konsep dan keterampilan berpikir kritis siswa SMP pada topik cahaya. Bandung: FPMIPA UPI, 2010.

[16] C.M.N. Falah, S. Windyariani and S. Suhendar, "Peningkatan kemampuan berpikir kritis peserta didik melalui model pembelajaran Search, Solve, Create, And Share berbasis etnosains," Jurnal Penelitian Pendidikan Biologi, vol. 2, no. (1), pp. 25-32, 2018.

[17] N. Hatari, A. Widiyatmoko and P. Parmin, "Keefektifan Model Pembelajaran Search, Solve, Create, And Share (SSCS) Terhadap Keterampilan Berpikir Kritis Siswa," Unnes science education journal, vol. 5, no. (2), 2016.

[18] C.A. Lukitasari and W. Winarti, "Jurnal Berkala Fisika Indonesia, vol. 8 , no. (1), 2016

[19] D. Febriyanti, S. Ilyas and C. Nurmaliah, "Peningkatan keterampilan generik sains melalui penerapan model SSCS (Search, Solve, Create, and Share) pada materi mengklasifikasikan makhluk hidup di MTsN Model Banda Aceh," Jurnal Biologi Edukasi, vol. 6, no. (2), pp. 43, 2014 